\title{
A New Paradigm to Understand the Role of Entrepreneurship and Innovation in Supporting Regional Food Networks (RFNS)
}

\author{
Chyi-Lyi Kathleen Liang* \\ Director, Center for Environmental Farming Systems, North Carolina Agricultural and Technical State University, USA
}

Submission: December 21, 2017; Published: January 09, 2018

"Corresponding author: Chyi-Lyi Kathleen Liang, Director, Center for Environmental Farming Systems, North Carolina Agricultural and Technical State University, 105 B Coltrane Hall, Greensboro, NC 27411, USA, Tel: 3362854683; Email: cliang@ncat.edu

\section{Opinion}

The recent "local food" movement emerging across the United States has touted the assumed social, ecological, and economic benefits of producing and consuming at the localto-regional level. Conventional approaches in studying food systems primarily focus on supply, demand, and intermediary services across agricultural and food industries. More recently, scholars have recognized a critical need to study the integrated nature of the Regional Food Networks (RFNs) beyond food systems, due to new discoveries of entrepreneurial farmers and organizations They introduced food as one of the best ways to strengthen relationships and values in a community. While farmers and farm families are often not in the spotlight of entrepreneurship studies, many farm families in both rural and urban communities have designed and implemented creative entrepreneurial strategies to provide services and benefits beyond consumption of food and fiber. For example, recent literature supports entrepreneurial farmers' involvement in designing and implementing multifunctional operations such as agritourism (e.g. farm tours, pick-your-own, educational workshops, seasonal festivals), value added (e.g. pie, jam, jelly, pickled vegetables), direct sales (e.g. farm to schools, farmers' coop, farmers' market), and off-farm employment to strengthen the relationships between agriculture and communities. These multifunctional operations and entrepreneurial activities contribute significantly to re-envisioning the future of agriculture and potential improvement of long-term farm profitability, food security, and community resilience.

The unfamiliar dynamics of the RFNs challenge scholars to gain deeper understanding of how entrepreneurial and innovative concepts of RFNs contribute to resilience at both the enterprise level and the community level. A network consists of intellectual and emotional domains - such as attachment, trust and confidence - tied to decisions and actions. Among all

actors within the RFNs, there are three possible categories of interactions:

a. Each actor makes independent decisions leading to independent outcomes; for example, each producer decides what to produce, how to produce, and when to produce based on her/his own knowledge and experiences. Each household decides locations of grocery shopping depending on preference, budget, and convenience. In this case, there is very limited relationship or interaction between producers and consumers in the RFN, which might create gaps to hinder innovation and efficiency for both producers and consumers.

b. Everyone makes decisions depending on others' decisions/behaviors; for example, farmers make decisions about when to harvest and where to sell their produce depending on wholesale buyers' preferences. Retailers acquire food from the wholesale, and consumers buy from retailers. In this case, farmers rely on the wholesale market to coordinate decisions and consumers purchase whatever is available in the retail market. The communication and relationship between farmers, wholesale, retail, and consumers need to be consistent and transparent to achieve the highest efficiency. Entrepreneurial ideas may occur at any level of connections. There is always a chance that someone takes the lead to come up innovative ideas that will benefit everyone (e.g. mobile food order and delivery). However, the innovative ideas must be fully explained to everyone and have to ensure positive outcomes for all.

c. Inter-dependent decisions represent a reasonable level for each actor to make independent decisions, however each decision may follow some agreed upon conditions among participants; for example, farmers can make decisions to 
sell to wholesale and to local farmers' market. If farmers sell to wholesale, the wholesaler determines a price range to pay farmers. If farmers decide to sell at a local farmers' market, each farmer has some flexibility to design their own promotion strategies and to determine a reasonable price range for consumers. In this case, farmers and consumers will meet and interact at the local market, receive feedback and exchange comments, and might even be able to negotiate an acceptable and satisfactory price/product mix.

The RFNs represent a broader spectrum of issues and interactions across food systems. There is a growing interest in studying entrepreneurial food strategies with respect to history, culture, preference, safety, health, and other topics that truly integrate economic, social, environmental, and political domains. There are many opportunities for actors across food systems to design, develop, implement, and engage in entrepreneurship and innovation. New products, new markets, new ways of doing business, and re-purposing existing resources to create new value added are just a few examples. Creating and sustaining entrepreneurial RFNs is particularly important to rural communities, where most rural enterprises employ fewer than 10 workers with limited access to resources, technology, information, and opportunity.

Here is a suggested pathway to explore and examine the role of entrepreneurship and innovation in the RFNs: a. To assemble and engage an inter-disciplinary team to include researchers and stakeholders that can truly identify local/regional issues and benefits from sustaining RFNs involving enterprise development and innovations.

b. To design, develop, and implement an integrated framework through diversity of social, economic, environmental, and political resources in food systems/food security planning.

c. To derive network parameters to show how people and organizations actually connect and communicate with each other to create and implement entrepreneurial initiatives.

d. To assess local/regional entrepreneurial landscape and identify opportunities, barriers, and gaps with respect to supporting an effective and RFN.

e. To create a dynamic and transparent channel of information dissemination involving stakeholders to motivate and incentivize community engagement in supporting entrepreneurship and innovation in RFNs that will contribute to People (farmers, local residents in farming communities, and consumers), Place (communities and ecosystems), and Prosperity (farm income and profits, wellbeing of local communities, quality of life for farmers/farm families and consumers or local residents).

\author{
Your next submission with Juniper Publishers \\ will reach you the below assets \\ - Quality Editorial service \\ - Swift Peer Review \\ - Reprints availability \\ - E-prints Service \\ - Manuscript Podcast for convenient understanding \\ - Global attainment for your research \\ - Manuscript accessibility in different formats \\ ( Pdf, E-pub, Full Text, Audio) \\ - Unceasing customer service
}

Track the below URL for one-step submission https://juniperpublishers.com/online-submission.php 